\title{
PHYISCO CHEMICAL, RHEOLOGICAL, MICROBIOLOGICAL AND SENSORY CHARACTERISTICS OF YOGHURT SUPPLEMENTED WITH BARLEY AND WHITE OAT FLOURS
}

\author{
Ibrahim S. Badawi*1 ${ }^{* 1}$ M.R. Shahein ${ }^{2}$ and M.M. Metwally ${ }^{2}$ \\ 1. Direct. Agric., Arish, Minist. Agric. and Land Reclamation, Egypt \\ 2. Dept. Food and Dairy Sci., Fac. Environ. Agric. Sci., Arish Univ., Egypt
}

\begin{abstract}
Yoghurt was made from cow's milk supplemented with barley or white oat flour at levels of $(0.0,0.5,1.0,1.5$ and $2.0 \%)$ these additives decreased the coagulation time, increased the curd tension and decreased the whey syneresis of resultant yoghurt. Barley flour was more effective than white oat flours in this respect. Addition of both barley and white oat flours greatly increased the TS, TP and ash contents of resultant yoghurt. But these additives slightly decreased the fat content. Also these additives enhanced the acidity of resultant yoghurt. Total bacterial count of yoghurt of all treatments gradually increased during storage. Lactic acid bacterial count was higher in yoghurt fortified with these additives. These additives improved also the organoleptic characteristics of resultant yoghurt when they were added at level up to $1.0 \%$. Also barley flour was the most effective in this respect.
\end{abstract}

Key words: Barley, white oat flour, yoghurt, food additives

\section{INTRODUCTION}

Fermented milk such as Yoghurt is an important dairy product, particularly for consumers with lactose intolerance. Yoghurt is considered a healthy food because it contains viable bacteria that are considered probiotics. Milk and dairy products do not contain fibers. Fibers of different sources are added to products to increase cooking yield and water-holding capacity, reduce lipid retention, improve textural properties and structure, or reduce caloric content by acting as a bulking agent (Larrauri, 1999). Consumption of foods containing fibers may prevent or decrease gastrointestinal disorders (Elia and Cummings, 2007). Hypertension, coronary, hypercholesterolemia heart disease and cancer (Pereira et al., 2004; Mann, 2007).

Functional foods are products of great interest to many people, and it deal with nutritional, medical and healthy foods (Fadaei et al., 2013).

Yoghurt is a dairy product produced by lactic acid fermentation of milk. The bacteria used as yoghurt are known as "yoghurt culture containing "Lactobacillus delbrueckii subsp. bulgaricus and Streptococcus thermophilus". Fermentation of lactose by these bacteria produces lactic acid, which acts on milk protein to give yoghurt its texture and characteristic tang. Yoghurt is nutritionally rich in protein, calcium, riboflavin, vitamin $\mathrm{B}_{6}$ and $\mathrm{B}_{12}$. It has nutritional benefits beyond those of milk.

Men and women who are lactoseintolerance can sometimes tolerate yoghurt better than other dairy products, because part of lactose in the milk is converted to glucose and galactose, and partially fermented to lactic acid, by the bacterial culture (Kolars et al., 1984).

\footnotetext{
* Corresponding author: Tel.: +201064646933

E-mail address: magdrsh10@gmail.com
} 
Yoghurt containing live cultures has been found effective in a randomized trial for preventing antibiotic-associated diarrhea, (Ripudaman et al., 2003). Yoghurt and other fermented milk contribute to health with natural nutrients and enrich the intestinal flora with lactic acid bacteria (LAB) (Tamime, 2005).

The nutritional and potential therapeutic value of food is a key characteristic in the development of new value added products that are manufactured for health conscious consumers (Fernandez et al., 1998).

Oat (Avena sativa) is a type of caryopsis cereals which also called a groat, kernel or grain (Lapvetelainen et al., 1995). The other briefly examine the potential of barley's compounds in diseases prevention. Evidences were shown to support the positive impact of different compounds such as soluble and insoluble fiber and beta-glucan, on human health and disease prevention, (Hashemi, 2015). This study aimed to evaluate the effect of addition of different levels of white oat and barley flour to cow's milk for improving some functional properties of yoghurt

\section{MATERIALS AND METHODS}

\section{Materials}

Milk

Fresh Cow's milk with $12.26 \%$ TS, 3.51\% fat, $3.42 \%$ protein, $0.74 \%$ ash, $0.17 \%$ titratable acidity and $\mathrm{pH} 6.50$ was obtained from a private farm in North Sinai Governorate.

\section{Starter}

Yoghurt culture (Streptococcus thermophillus, Lactobacillus delbrueckii ssp. bulgaricus) were obtained from DANISCO, Rue de clemencieres-BP 32, Sassenage, AlDenemark.

\section{White oats and barley flours}

- White Oat flour was obtained from Al Ghurair Foods Company of Dubai, United Arab Emirates.
- Barley flour was obtained from Super market in North Sinai Governorate.

\section{Yoghurt Manufacture}

The nutritional additives (barley and white oats flour) were added to Cow's milk at levels of $(0.5 \%, 1.0 \%, 1.5 \%$ and $2.0 \%)$ then heated at $90^{\circ} \mathrm{C} / 15 \mathrm{~min}$, then cooled to $42^{\circ} \mathrm{C}$; then inoculated with $3 \%$ yoghurt starter, (Streptococcus thermophillus, Lactobacillus delbrueckii ssp. bulgaricus).

Then milk of Each treatment was distributed into $100 \mathrm{ml}$ in plastic cups, the cups were incubated at $42^{\circ} \mathrm{C}$ for $3-4$ hours until a firm curd was formed. The resultant yoghurt of all treatments was kept in a refrigerator $\left(5^{\circ} \mathrm{C}\right)$ for 14 days.

\section{Methods}

\section{Coagulation Time}

The coagulation time which was taken as a measure of the starter activity was observed by the visual method used by Berridge (1952) and Davies and White (1958). The starting of coagulation time of each milk sample in seconds was recorded.

\section{Curd Tension}

The curd tension of resultant yoghurt was determined by using the method described by (Chandrasekhara et al., 1957). The rate of yoghurt curd syneresis at room temperature $\left(25-30^{\circ} \mathrm{C}\right)$ was measured as given by Mehanna (1989).

\section{Chemical Analysis}

- Total solids; total protein and ash contents of resultant yoghurt were determined according to the method of AOAC (2011).

- Titratable acidity was determined according to the method of AOAC (2011) treatment no. (33.2.06).

- pH values were measured using JENWAY Digital pH meter Model 3310.

- Fat content of milk samples was determined by the Gerber method as described by AOAC (2011) treatment no. (33.2.27A). 
Chemical composition of white oats and barley flours

\begin{tabular}{ccc}
\hline Composition (\%) & White oat flour & Barley flour \\
\hline Total protein & 11.0 & 12.2 \\
Fat & 8.0 & 2.12 \\
Total carbohydrates & 60.0 & 71.49 \\
Fibers & 8.5 & 6.85 \\
Ash & 4.8 & 3.64 \\
\hline
\end{tabular}

\section{Micobiological Analysis}

\section{Total viable bacterial counts}

Total bacterial counts of yoghurt samples were enumerated on nutrient agar medium being prepared according to (Difico, 1971).

\section{Coliform Group}

Mconkey agar plate was adopted to enumerate the coliform group using the method described in (The Standard methods for examination of milk and dairy products, 1960).

\section{Mould and Yeast Counts}

Mould and yeast were counted on potato dextrose agar (PDA) medium according to (Difico, 1971).

\section{Lactic Acid Bacteria}

Enumeration of lactic acid bacteria was carried out on (MRS) medium being prepared according to (Difico, 1971).

\section{Organoleptic properties of yoghurt}

Yoghurt samples were evaluated according to the method described by (Scott, 1981).

\section{RESULTS AND DISCUSSION}

\section{Rheological Properties}

\section{Coagulation Time}

Results presented in Table 1 show that addition of barley and white oat flours decreased the acid coagulation time of the resultant yoghurt as compared with control treatment. Also it could be noticed that as the level of the additives was increased the coagulation time was decreased.
Firmness is an important character for evaluation the fermented milk. It could be noticed that barley treatments gave very firm coagulation compare with oat treatments.

\section{Curd Tension and Syneresis}

Results presented in Table 1 indicate that addition of white oat flour at the different levels didn't show remarkable effect on both curd tension and whey syneresis. However addition of barley flour to cow's milk yoghurt increased the curd tension and decreased the whey syneresis of resultant Yoghurt.

\section{Chemical Properties of Resultant Yoghurt}

\section{Acidity and pH}

Results presented in Table 2 indicate that these additives enhanced the acidity development in cow's milk Yoghurt. The most effective additives in this respect was barley flour which showed the highest acidity and lowest $\mathrm{pH}$ values. Moreover acidity content of yoghurt of all treatments slightly increased with the advance of storage period and this was associated with a decrease in $\mathrm{pH}$ values.

\section{TP/DM and TS}

Results shown in Table 3 indicate that addition of barley and white oat flours to whole cow's milk yoghurt increased the TS and T.P/DM of resultant yoghurt, Also Gogo et al. (2012) found that addition of egg white to milk yoghurt increased the total protein. 
Table (1): Effect of addition barley and white oat flours on the coagulation time, firmness curd tension and syneresis of yoghurt.

\begin{tabular}{|c|c|c|c|c|c|}
\hline Treatment & $\begin{array}{l}\text { Addition } \\
(\%)\end{array}$ & $\begin{array}{l}\text { Coagulatin } \\
\text { time (min) }\end{array}$ & Remarks & $\begin{array}{c}\text { Curd } \\
\text { tension }(g)\end{array}$ & $\begin{array}{l}\text { Syneresis }(\mathrm{ml} . \\
\text { of whey/100g) }\end{array}$ \\
\hline \multirow[t]{2}{*}{ Control } & 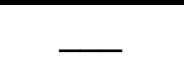 & 183 & Firm & 25.90 & 33.78 \\
\hline & 0.5 & 168 & $\begin{array}{c}\text { Firm- normal color of cow } \\
\text { yoghurt }\end{array}$ & 38.42 & 29.81 \\
\hline \multirow{4}{*}{$\begin{array}{l}\text { Barley } \\
\text { flour }\end{array}$} & 1.0 & 162 & More firm & 38.50 & 28.63 \\
\hline & 1.5 & 160 & Very firm & 38.53 & 27.50 \\
\hline & 2.0 & 159 & Highly firm & 38.60 & 26.73 \\
\hline & 0.5 & 177 & $\begin{array}{l}\text { Firm and the color tends to } \\
\text { white }\end{array}$ & 26.20 & 35.32 \\
\hline \multirow{3}{*}{$\begin{array}{l}\text { White oat } \\
\text { flour }\end{array}$} & 1.0 & 171 & $\begin{array}{l}\text { Firm and the color tends to } \\
\text { white }\end{array}$ & 26.80 & 34.66 \\
\hline & 1.5 & 164 & $\begin{array}{l}\text { Firm and the color tends to } \\
\text { white }\end{array}$ & 26.81 & 33.76 \\
\hline & 2.0 & 160 & $\begin{array}{l}\text { Firm and the color tends to } \\
\text { light white }\end{array}$ & 26.90 & 32.90 \\
\hline
\end{tabular}

Table (2): Effect of addition barley and white oat flours on the acidity and $\mathrm{pH}$ of yoghurt during storage up to 14 days at $5^{\circ} \mathrm{C}$.

\begin{tabular}{|c|c|c|c|c|c|c|c|}
\hline \multirow[t]{3}{*}{ Treatment } & \multirow{3}{*}{$\begin{array}{c}\text { Addition } \\
(\%)\end{array}$} & \multicolumn{3}{|c|}{ Acidity (lactic acid \%) } & \multicolumn{3}{|c|}{ pH } \\
\hline & & \multicolumn{3}{|c|}{ Storage period (day) } & \multicolumn{3}{|c|}{ Storage period (day) } \\
\hline & & $\mathbf{0}$ & 7 & 14 & $\mathbf{0}$ & 7 & 14 \\
\hline \multirow[t]{2}{*}{ Control } & 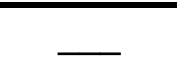 & 0.960 & 1.040 & 1.110 & 4.28 & 4.23 & 4.22 \\
\hline & 0.5 & 1.145 & 1.224 & 1.283 & 4.16 & 4.13 & 4.00 \\
\hline \multirow{3}{*}{ Barley flour } & 1.0 & 1.235 & 1.315 & 1.372 & 4.14 & 3.98 & 3.93 \\
\hline & 1.5 & 1.273 & 1.363 & 1.410 & 4.10 & 3.94 & 3.91 \\
\hline & 2.0 & 1.324 & 1.382 & 1.410 & 3.96 & 3.92 & 3.90 \\
\hline \multirow{4}{*}{ White oat flour } & 0.5 & 0.979 & 1.072 & 1.130 & 4.26 & 4.20 & 4.00 \\
\hline & 1.0 & 1.081 & 1.102 & 1.175 & 4.21 & 4.16 & 4.15 \\
\hline & 1.5 & 1.130 & 1.149 & 1.210 & 4.17 & 4.15 & 4.14 \\
\hline & 2.0 & 1.210 & 1.229 & 1.270 & 4.13 & 4.13 & 4.11 \\
\hline
\end{tabular}


SINAI Journal of Applied Sciences (ISSN: 2314-6079) Vol. (5) Is. (3), Dec. 2016

Table (3): Effect of addition barley and white oat flours on the TS and TP (\%) of yoghurt during storage up to 14 days at $5^{\circ} \mathrm{C}$.

\begin{tabular}{lccccccc}
\hline Treatment & $\begin{array}{c}\text { Addition } \\
(\mathbf{\%})\end{array}$ & \multicolumn{3}{c}{ TS } & \multicolumn{4}{c}{ TP/DM } \\
\cline { 3 - 8 } & & \multicolumn{2}{c}{ Storage period (day) } & \multicolumn{3}{c}{ Storage period (day) } \\
\cline { 3 - 8 } & & 13.00 & 13.15 & 13.31 & 27.69 & 28.14 & 28.92 \\
\hline Control & $\mathbf{0 . 5}$ & 16.31 & 16.46 & 16.59 & 32.53 & 32.42 & 32.85 \\
& $\mathbf{1 . 0}$ & 16.77 & 16.87 & 16.98 & 32.26 & 32.55 & 32.43 \\
Barley flours & $\mathbf{1 . 5}$ & 17.21 & 17.37 & 17.53 & 33.18 & 33.15 & 33.47 \\
& $\mathbf{2 . 0}$ & 17.72 & 17.88 & 18.13 & 33.30 & 32.35 & 33.45 \\
& $\mathbf{0 . 5}$ & 14.09 & 14.24 & 14.39 & 31.73 & 31.65 & 31.53 \\
White oat flour & $\mathbf{1 . 0}$ & 14.71 & 14.89 & 14.91 & 31.55 & 31.48 & 31.64 \\
& $\mathbf{1 . 5}$ & 15.18 & 15.33 & 15.46 & 31.81 & 32.19 & 32.22 \\
& $\mathbf{2 . 0}$ & 16.14 & 16.26 & 16.39 & 32.52 & 32.55 & 32.49 \\
\hline
\end{tabular}

\section{Fat/DM and Ash/DM}

Results presented in Tables 4 indicate that different additives resulted in remarkable increase in Ash/DM of resultant yoghurt and this increase was associated with the level of addition.

However these additives slightly decreased fat content of resultant yoghurt. Moreover it could be noticed that TS, TP, Fat and Ash contents of yoghurt from the different treatments slightly increased with the advance of storage period.

\section{Microbiological Evaluation}

\section{Total bacterial count}

Table 5 shows the effect of different concentrations of barley and white oat flours on total bacterial count of yoghurt during storage up to 14 days at $5^{\circ} \mathrm{C}$. Results indicated that total bacterial count of yoghurt from all treatments gradually increased with the advance of storage period.

Results also indicated that these additives did not affected the total bacterial count of resultant yoghurt up to the end of storage period. Concerning lactic acid bacteria count (LAB), it could be noticed from data presented in Table 5 that both barley and white oat flours yoghurt supplemented with showed higher LAB count than control one. Also LAB count of yoghurt from all treatments decreased with the advance of storage period.

\section{Moulds and yeast}

Generally within each additive treatments, moulds and yeast decreased compared with control treatments and increased within storage time on contrast LAB.

\section{Coliform}

Coliform were absent in all treatments either when fresh or during storage period up to 14 days at $5^{\circ} \mathrm{C}$, this indicated that the preparing of Cow's milk yoghurt was in good and clean condition.

\section{Organoleptic Properties}

Organoleptic scoring of yoghurt from the different treatments are shown in Table 6. Results indicate that addition of barley and white oat flour at level of $0.5 \%$ and $1.0 \%$ had the highest values of the total score of resultant yoghurt. Increasing the level of the addition resulted in decreasing the total score of resultant cow's milk yoghurt. 
Table (4): Effect of addition barley and white oat flours on the Fat/DM and Ash/DM of yoghurt during storage up to 14 days at $5^{\circ} \mathrm{C}$

\begin{tabular}{lccccccc}
\hline Treatment & $\begin{array}{c}\text { Addition } \\
\text { (\%) }\end{array}$ & \multicolumn{3}{c}{ Fat/DM } & \multicolumn{3}{c}{ Ash/DM } \\
\cline { 3 - 8 } & & \multicolumn{2}{c}{ Storage period (day) } & \multicolumn{3}{c}{ Storage period (day) } \\
\cline { 3 - 8 } & & $\mathbf{0}$ & $\mathbf{7}$ & $\mathbf{1 4}$ & $\mathbf{0}$ & $\mathbf{7}$ & $\mathbf{1 4}$ \\
\hline Control & $\mathbf{0 . 5}$ & 32.310 & 33.460 & 34.560 & 4.770 & 5.033 & 5.375 \\
& & 31.000 & 31.831 & 32.187 & 6.575 & 6.944 & 7.309 \\
Barley flour & $\mathbf{1 . 0}$ & 31.225 & 32.000 & 32.198 & 7.833 & 8.054 & 8.400 \\
& $\mathbf{1 . 5}$ & 31.420 & 32.241 & 32.560 & 9.074 & 9.400 & 9.574 \\
& $\mathbf{2 . 0}$ & 31.558 & 32.258 & 32.723 & 9.495 & 9.722 & 9.958 \\
& $\mathbf{0 . 5}$ & 30.071 & 30.990 & 32.100 & 6.523 & 6.870 & 7.305 \\
White oat flour & $\mathbf{1 . 0}$ & 30.076 & 31.000 & 32.148 & 7.824 & 8.041 & 8.300 \\
& $\mathbf{1 . 5}$ & 30.079 & 31.026 & 32.150 & 9.043 & 9.352 & 9.560 \\
& $\mathbf{2 . 0}$ & 30.081 & 31.027 & 32.356 & 9.374 & 9.655 & 9.912 \\
\hline
\end{tabular}

Table (5): Effect of addition barley and white oat flours on the total bacterial count (TC) and on the lactic acid bacteria (LAB) of yoghurt during storage up to 14 days at $5^{\circ} \mathrm{C}$.

\begin{tabular}{|c|c|c|c|c|c|c|c|}
\hline \multirow[t]{3}{*}{ Treatment } & \multirow[t]{3}{*}{$\begin{array}{c}\text { Addition } \\
(\%)\end{array}$} & \multirow{2}{*}{\multicolumn{3}{|c|}{$\begin{array}{c}\text { Total bacterial count (TC) } \\
\text { cfu ml }^{-1}\end{array}$}} & \multirow{2}{*}{\multicolumn{3}{|c|}{$\begin{array}{l}\text { Lactic acid bacteria } \\
\text { (LAB) cfu } \mathrm{ml}^{-1} \\
\text { Storage period (day) }\end{array}$}} \\
\hline & & & & & & & \\
\hline & & $\mathbf{0}$ & 7 & 14 & $\mathbf{0}$ & 7 & 14 \\
\hline \multirow[t]{2}{*}{ Control } & 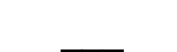 & 22 & 89 & 350 & 4 & 1 & 0 \\
\hline & 0.5 & 16 & 77 & 300 & 5 & 4 & 2 \\
\hline \multirow{4}{*}{ Barley flour } & 1.0 & 18 & 81 & 302 & 5 & 4 & 3 \\
\hline & 1.5 & 19 & 85 & 311 & 5 & 4 & 4 \\
\hline & 2.0 & 20 & 86 & 319 & 6 & 5 & 4 \\
\hline & 0.5 & 18 & 80 & 319 & 4 & 3 & 2 \\
\hline \multirow{3}{*}{ White oat flour } & 1.0 & 20 & 83 & 322 & 4 & 4 & 2 \\
\hline & 1.5 & 21 & 88 & 330 & 5 & 4 & 3 \\
\hline & 2.0 & 33 & 93 & 337 & 5 & 4 & 4 \\
\hline
\end{tabular}


SINAI Journal of Applied Sciences (ISSN: 2314-6079) Vol. (5) Is. (3), Dec. 2016

Table (6): Effect addition of barley and white oats flour on organoleptic properties of yoghurt during storage up to 14 days at $5^{\circ} \mathrm{C}$.

\begin{tabular}{|c|c|c|c|c|c|c|}
\hline Treatment & & $\begin{array}{c}\text { Storage } \\
\text { period (day) }\end{array}$ & $\begin{array}{c}\text { Color and } \\
\text { appearance (15) }\end{array}$ & $\begin{array}{c}\text { Body and } \\
\text { texture (35) } \\
\end{array}$ & $\begin{array}{c}\text { Flavour } \\
(\mathbf{5 0 )} \\
\end{array}$ & $\begin{array}{l}\text { Total } \\
(100) \\
\end{array}$ \\
\hline \multirow{4}{*}{ Control } & \multirow{3}{*}{ ـ } & 0 & 12 & 30 & 45 & 87 \\
\hline & & 7 & 10 & 27 & 42 & 79 \\
\hline & & 14 & 6 & 23 & 36 & 65 \\
\hline & \multirow{4}{*}{0.5} & 0 & 13 & 33 & 43 & 89 \\
\hline \multirow{11}{*}{ Barley flour } & & 7 & 11 & 30 & 42 & 83 \\
\hline & & 14 & 10 & 29 & 40 & 79 \\
\hline & & 0 & 13 & 34 & 42 & 89 \\
\hline & \multirow[t]{3}{*}{1.0} & 7 & 11 & 30 & 41 & 82 \\
\hline & & 14 & 10 & 29 & 40 & 79 \\
\hline & & 0 & 12 & 34 & 41 & 87 \\
\hline & \multirow[t]{3}{*}{1.5} & 7 & 10 & 30 & 40 & 80 \\
\hline & & 14 & 9 & 28 & 40 & 77 \\
\hline & & 0 & 12 & 35 & 41 & 88 \\
\hline & \multirow{3}{*}{2.0} & 7 & 9 & 30 & 40 & 79 \\
\hline & & 14 & 8 & 28 & 39 & 75 \\
\hline \multirow{12}{*}{ White oat flour } & & 0 & 13 & 32 & 43 & 88 \\
\hline & \multirow[t]{3}{*}{0.5} & 7 & 11 & 29 & 43 & 83 \\
\hline & & 14 & 11 & 28 & 36 & 75 \\
\hline & & 0 & 12 & 32 & 44 & 88 \\
\hline & \multirow[t]{3}{*}{1.0} & 7 & 11 & 30 & 43 & 84 \\
\hline & & 14 & 10 & 29 & 35 & 74 \\
\hline & & 0 & 12 & 32 & 43 & 87 \\
\hline & \multirow[t]{3}{*}{1.5} & 7 & 10 & 30 & 42 & 82 \\
\hline & & 14 & 9 & 30 & 33 & 72 \\
\hline & & 0 & 12 & 32 & 43 & 87 \\
\hline & \multirow[t]{2}{*}{2.0} & 7 & 10 & 30 & 35 & 75 \\
\hline & & 14 & 9 & 30 & 30 & 69 \\
\hline
\end{tabular}

Also it could be noticed that these additives greatly improved the body and texture of resultant yoghurt.

Total score of yoghurt of all treatments slightly decreased during the progress of storage period. From the obtained results it could be concluded that addition of barley or white oat flour up to $1.0 \%$ to cow's milk enhanced the total score of resultant yoghurt compared with the other treatments from barley or white oat flours. Fernandez et al. (1998) reported that oat increased the apparent viscosity of yoghurt, while Ahmed et al. (2010) mentioned that water binding capacity of B-glucan products increased than control products.

\section{CONCLUSION}

From the obtained results addition of barley or white oat flours at level up to $1.0 \%$ to yoghurt could be recommended. These additives resulted in improving the rheological properties of resultant yoghurt, Also this additives increased total solids and total protein contents of resultant yoghurt and improved the organoleptic properties of resultant yoghurt. 


\section{REFERENCES}

Ahmed, A.; Muhammad, A.F.; Tahir, Z.; Haq, N. and Zaheer, A. (2010). Extraction and characterization of \{beta\}-d-glucan from oat for industrial utilization. Int. J. Biolog. Macro., 46 (3): 304-309.

AOAC (2011). Association of Official Analytical Chemists. Official Methods of Analysis. $17^{\text {th }}$ Ed., Gaithersburg, M D, USA.

Berridge, N.J. (1952). Some observation on the determination of the activity of rennet. Analyst, 77 : 57-62.

Chandrasekhara, M.R.; Bhagawan, R.K.; Swamminathan, M. and Subrahmanyan, V. (1957). The use of mammalian milk and processed milk foods in the feeding of infants. Indain J. Child. Health, D, 70L.

Davies, D.T. and White, J.C.D. (1958). The relation between the chemical composition of milk and the stability of the caseinate complexs. II. Coagulation by ethanoil. J. Dairy Res., 25:256-266.

Difico, M. (1971). Dehydrated culture media and reagents for microbial and chemical laboratory procedure, $9^{\text {th }}$ edition. Pub. Difico Laboratory, Inc. Detriot, Michigan, USA.

Elia, M. and Cummings, J.H. (2007). Physiological aspects of energy metabolism and gastrointenstinal effects of carbohydrates. Eur. J. Clin. Nutr., 61 (1): 40-74.

Fadaei, V.; Mohamadi-Alasti1, F. and Khosravi-Darani K. (2013). Influence of Spirulina platensis powder on the starter culture viability in probiotic yoghurt containing spinach during cold storage. Europ. J. Exp. Biol., 3 (3): 389-393.
Fernandez, E.G.; Mcgregor, J.U and Traylor, S. (1998). The addition of oat fiber and natural alternative sweeteners in the manufacture of plain yoghurt. J. Dairy Sci., 81: 655-663.

Gogo, L.A.; Gogo, K.O.; Shalo, P.L. and Mahungu, S.M. (2012). Effect of egg white utilization on the physico-chemical and sensory attributes of protein-rich yoghurt. Int. J. Food Studies, 1 (1): 52-62.

Hashemi, J.M. (2015). Biomedical Effects of Barley-A Review. NY. Sci. J., 8 (3): 52-55.

Kolars, J.C.; Levitt, M.D.; Aouji, M. and Savaiano, D.A. (1984). Yoghurt an autodigesting source of lactose. N. Eng. J., $310: 1-3$.

Lapvetelainen, A.; Bietz, J.A. and Huebner, F.R. (1995). Reversed-phase high-performance liquid chromatography of oat proteins: application to cultivar comparison and analysis of the effect of wet processing.

Larrauri, J.A. (1999). New approaches in the preparation of high diatery fiber powders from fruit by-products. Trends Food Sci. Technol., 10:3-8.

Mann, J. (2007). Dietary carbohydrates: relationship to cardiovascular disease and disorders of carbohydrate metabolism. Eur. J. Clin. Nutr., 61 (1): 100-111.

Mehanna, N.M. and Mehanna, A.S. (1989). Studies on the use of stabilizer for improving some properties of cow's milk yoghurt. Egypt. J. Dairy Sci., 17: 289-296.

Pereira, M.A.; O'Reilly, E. and Augustsson, K. (2004). Dietary fiber and risk of coronary heart disease: Apooled analysis of cohort studies. Arch. Int. Med., 164:370-37. 
Ripudaman, S.B.; Vincent, C.A.; Leno, T., Sudhir, N.; Thomas, F.I.; Rauf, A.C. and Usman, A.A. (2003). A randomized trial of Yoghurt for prevention of antibiotic-associated diarrhea. Digestive Dis. and Sci., 48 (10): 2077-2082.
Scott, R (1981). Cheese making practice, Applied Sci. Publishers LTD., NY, 361383.

Tamime, A.Y. (2005). Probiotic dairy products. Blackwell Publishing, Oxford, UK, 98-115. 


\section{الملخص العربى}

\section{تـأثير إضافة دقيق الشعير والثوفان على الخصائص الفيزوكيميائية والريولوجية} والميكروبيولوجية والئية والحسية للزبادي

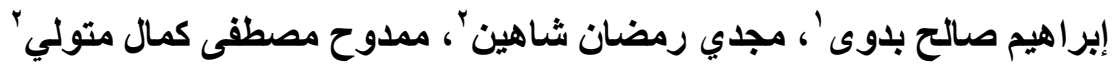

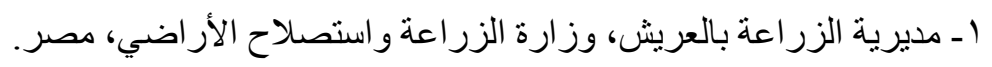

rـ قسم علوم وتكنولوجيا الأغذية و الألبان، كلية العلوم الزر اعبة البيئية، جامعة العريش، مصركر.

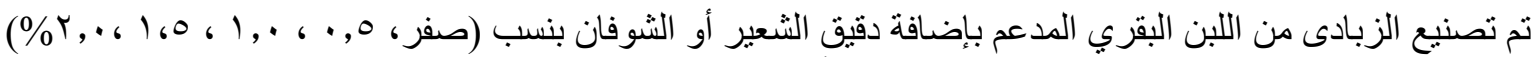

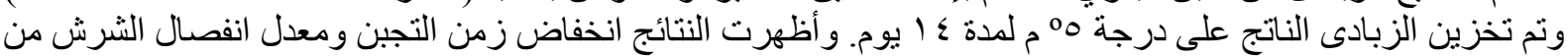

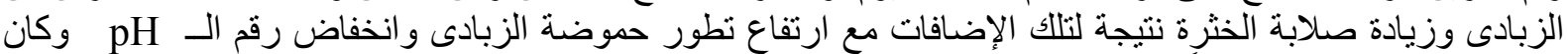

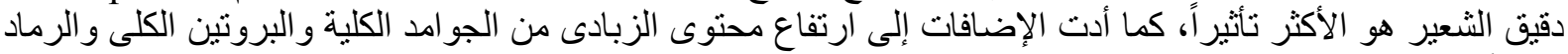

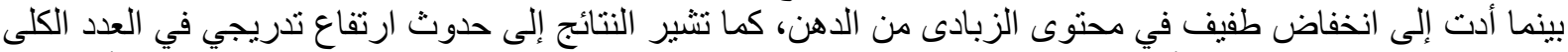

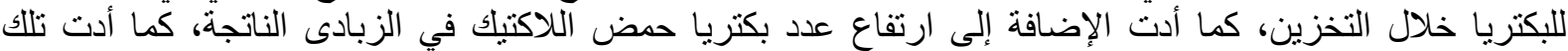

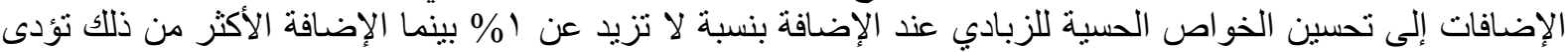
إلى انخفاض الخو اص الحسية للزبادي الناتج. الكلمات الإسترشادية: دقيق الثعير، دقيق الثوفان، الزبادي. 